\title{
Study on Maize Stalk Lodging Resistance in Cyclic Cross Selection
}

\author{
Andreea ONA ${ }^{1 *}$, Leon MUNTEAN ${ }^{1}$, Voichița HAȘ², Nicolae TRITEAN ${ }^{2}$ \\ ${ }^{1}$ Department of Plant Breeding, Faculty of Agriculture, University of Agricultural Sciences and Veterinary \\ Medicine Cluj-Napoca \\ ${ }^{2}$ Agricultural Research and Development Station Turda \\ *corresponding author, e-mail: andreea.ona@gmail.com
}

Bulletin USAMV series Agriculture 74(2)/2017

Print ISSN 1843-5246; Electronic ISSN 1843-5386

DOI 10.15835/buasvmcn-agr: 0005

\begin{abstract}
Stalk lodging resistance is a particularly important trait on maize, especially in terms of mechanized harvesting of the crop. Stalk lodging represents a major problem of corn with yield losses. Because of this reason, it takes a special attention on the breeding process. The purpose of this research was the study of maize stalk lodging resistance before the harvest time and finding the best breeding lines for this type of resistance. We used 7 breeding lines (TE 229, TE 202B, TA 452, TE 330A, TD 364, TE 317 and TE 335) as maternal lines and another 3 (TD 268, TC 385A and TC 399) as testers. Lines were tested in 2011 and 2012, in compared cultures with 24 variants, where 21 of them were the experimental hybrids between tested lines and testers and the other 3 were the control hybrids Turda 201, Turda Favorit and PR39D81. Variance analysis was performed according to the classical model of a two-factor system. Genic effects were calculated after $2^{\text {nd }}$ North Carolina model. Regarding the results, the highest percentage of unbroken plants was on TD 268 tester (80.7\%) and the lowest on TD 364 tested line $(70.2 \%)$. Tested lines that was noted for the general combining ability of lodging resistance were TA 452 and TE 335. Crossings that marked high values for non-additive effects were TA $452 \mathrm{x}$ TC 385A, TE 202B x TC 399 and TE 202B x TD 268. Effects values for general combining ability were between $-4.72 \%$ and $+4.49 \%$ on tested lines, $-1.68 \%$ and $+5.78 \%$ on testers; effects values for specific combining ability were between $-11.25 \%$ and $+7.58 \%$. Regarding the tested lines was noted TA 452 inbred line and regarding the testers was noted TD 268 inbred line. On this issue, we can state that in the selection process of maize hybrids must be chosen only those hybrid combinations with stalk-lodging resistance because of the similar contribution of additive and non-additive genic effects to resistant genotypes.
\end{abstract}

Keywords: additive effects, genetical variances, non-additive effects, non-orthogonal decomposition, stalk lodging resistance.

\section{INTRODUCTION}

Due the importance of maize, one of the most important cereal worldwide, a series of measures have been taken to increase yield, including some breeding programs to improve the stalk lodging resistance. An incomplete understanding of stalk lodging impedes efforts to improve maize production (Robertson et al., 2017). Yield losses in maize due to stalk lodging negatively impact farmers and affect the whole society because of the instability created in the overall crop supply (Robertson etal., 2016). These losses are estimated to range from 5-20\% annually worldwide (FlintGarcia et al., 2003).

Therefore stalk lodging resistance before harvesting is one of the major targets of maize breeding projects, especially as it can influence final yield by increasing grain loss and reduce grain quality (Hallauer et al., 2010). Also, maize lodging 
adds the obstacle to mechanical harvesting and restricted planting density (Yang et al., 2016).

One direction for increasing lodging resistance over the past 100 years was artificial selection (Larsson et al., 2017). Because lodging is a major stress of maize, other path for improving the efficiency of plants resistance, high stress location must be selected as a test environment (Liu et al., 2010). Huang et al. (2014) recommended that when choosing the corn varieties with lodging resistance, both morphological and physiology indexes should be taken into consideration synthetically. To decrease the risk of lodging should be applied rational close planting and fertilization (Lu et al., 2015). Also, strong stalks reduce lodging and maximize harvestable yield (Peiffer et al., 2013).

Stalk lodging resistance is a complex phenomenon due morphophysiological factors, environmental conditions, diseases and pests attack, but also because the interaction between these factors. Many of the involved factors in this type of resistance are strongly correlated with each other. Stalk lodging resistance on technical maturity is strongly correlated with the stalkrot resistance caused by Fusarium spp. and with

Tab. 1. Rainfalls and average air temperature during the 2011 and 2013 growing seasons

\begin{tabular}{lcccccc}
\hline \multirow{2}{*}{ Month } & \multicolumn{3}{c}{ Rainfalls $(\mathrm{mm})$} & \multicolumn{3}{c}{ Average temperature $\left({ }^{\circ} \mathrm{C}\right)$} \\
\cline { 2 - 7 } & 2011 & 2012 & 50 years average & 2011 & 2012 & 50 years verage \\
\hline April & 22.6 & 78.4 & 46.1 & 10.7 & 11.8 & 9.8 \\
\hline May & 41.4 & 89.2 & 67.4 & 15.6 & 16.2 & 14.8 \\
\hline June & 116.8 & 67.4 & 80.6 & 19.2 & 21.0 & 17.8 \\
\hline July & 130.4 & 52.4 & 74.7 & 20.1 & 24.0 & 19.5 \\
\hline August & 12.8 & 28.0 & 57.0 & 20.8 & 22.3 & 19.4 \\
\hline September & 22.8 & 30.2 & 40.0 & 18.2 & 19.1 & 14.9 \\
\hline
\end{tabular}

(Source of primary data: Turda Weather Station $\left(46^{\circ} 35^{\prime}\right.$ latitude, $23^{\circ} 47^{\prime}$ longitude, $427 \mathrm{~m}$ altitude))

Tab. 2. Corn inbred lines used on cyclic crossing system

\begin{tabular}{lcll}
\hline \multicolumn{2}{c}{ Inbred line } & Created by & \multicolumn{1}{c}{ Line origin (Genealogy no.) } \\
\hline & & & Tester inbred lines \\
\hline 1. & TD 268 & Turda ARDS & Sel. from TC208xC103 / 5370-2-2-4-2- \\
\hline 2. & TC 385A & Turda ARDS & Sel. from Comp B (C103, Mo17, T248, TC208, W633) / H60-1-1-1 \\
\hline 3. & TC 399 & Turda ARDS & Sel. from Comp B (C103, Mo17, T248, TC208, W633) / H84-6-7-2 \\
\hline & & & Tested inbred lines \\
\hline 1. & TE 229 & Turda ARDS & Sel. from Raissa / 6597-3-6- \\
\hline 2. & TE 202B & Turda ARDS & Sel. from Raissa / 6600-1-1-1- \\
\hline 3. & TA 452 & Turda ARDS & Sel. from commercial hybrid / 9390-5-1-2 \\
\hline 4. & TE 330A & Turda ARDS & Sel. from commercial hybrid / 9626-3-1 \\
\hline 5. & TD 364 & Turda ARDS & Sel. from Raissa / 8340-1-1-3- \\
\hline 6. & TE 317 & Turda ARDS & Sel. from Raissa / 8345-1-5-1- \\
\hline 7. & TE 335 & Turda ARDS & Sel. from commercial hybrid / 9509-1-5-3-1- \\
\hline
\end{tabular}

Source: ONA et al. (2013) 


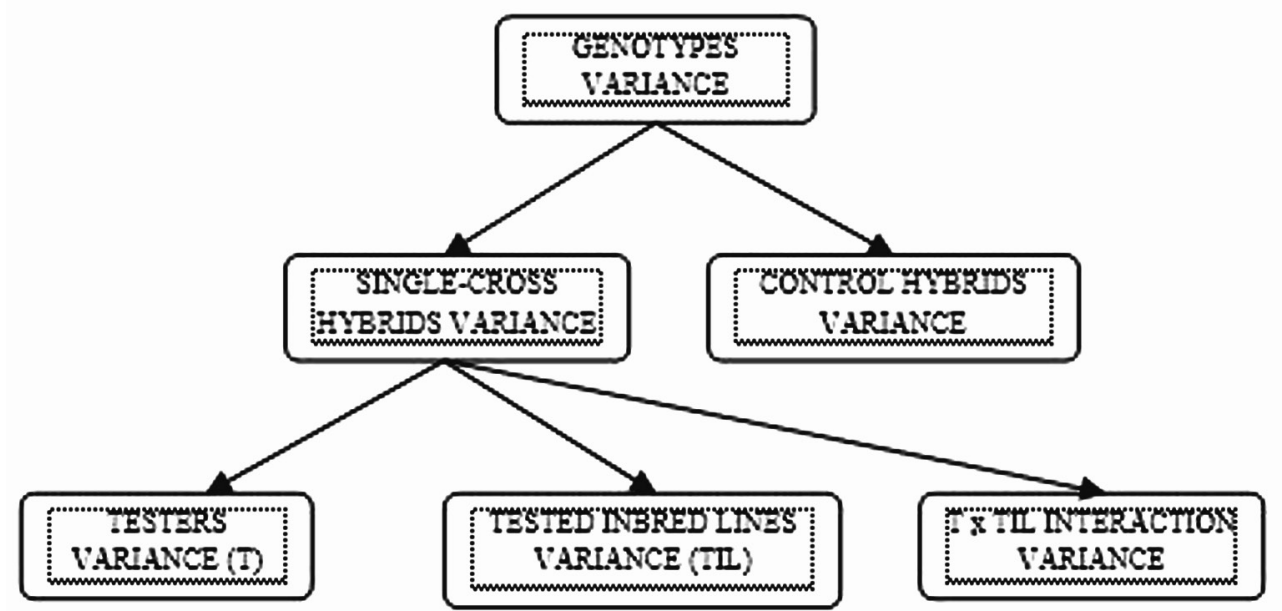

Fig. 1. Non-orthogonal decomposition of genotypes variance (Haș et al., 2010)

resistance to corn borer attack (Ostrinia nubilalis) (Suciu, 2009). Previous studies showed that high plant density involves reduced light intensity which is another important factor affecting maize lodging (Xue et al., 2016).

In terms of heredity of unbroken plants under the ears, a multitude of factors are involved, so the study of this character is particularly difficult and the progress made in the selection of this trait must be slow (Căbulea, 1981; Troyer, 1999; Haș, 2004).

Based on the above analysis, the main aim of the present paper is to study the resistance of stalks lodging before harvesting and to identify the best performing lines that transmit this character in order to create further resistent hybrids.

\section{MATERIALS AND METHODS}

\section{Experiment management}

Experiences were conducted at Turda Agricultural Research and Development Station located in northwest of Turda town from Transylvanian Plateau (46 $35^{\circ}$ N latitude, $23^{\circ} 47^{\prime} \mathrm{E}$ longitude, 345-493 m altitude).

Annual average temperature of air is $8.6^{\circ} \mathrm{C}$ with $-4.4^{\circ} \mathrm{C}$ average for the coldest month and $19.3^{\circ} \mathrm{C}$ average for the warmest mounth. Rainfalls annual average touches $503.2 \mathrm{~mm}$ (details in Table 1).

Experiences were cultivated after autumn wheat culture using a density of 60.000 plants/ ha in a non-irrigated Luvic Chernozems ( $\mathrm{CH} \mathrm{lv}$ ) (WRB-SR-1998') type of soil.

World reference base for soil resources 2014

\section{Material}

Study material consisted of 7 inbred lines (TE 229, TE 202B, TA 452, TE 330A, TD 364, TE 317 and TE 335) used as maternal lines and 3 inbred lines (TD 268, TC 385A and TC 399) used as paternal forms. Material was tested in 2011 and 2012 experimental years, in compared cultures of 24 variants each in 3 repetitions, where 21 variants were single-cross hybrids of tested lines and testers, and 3 variants were the control hybrids (Turda 201, Turda Favorit and PR39D81) (Tab. 2 ). The tested lines were obtained by inbreeding the commercial hybrids. Testers are originated from the Lancaster Sure Crop germplasm group. Test crossings were carried out in 2010 at Turda Agricultural Research and Development Station, and hybrids experiments were carried out in 2011 and 2012.

Both tested inbred lines and testers were created by Maize Breeding Laboratory of ARDS Turda (Haş et al., 2011).

\section{Methods}

Variance analysis was performed according to the classical model of a two-factor system: experimental years and 24 tested hybrids. Genotypes variance was non-ortogonally decomposed according to the model described by Haș et al. (2010) (Fig. 1). Genic effects were calculated after $2^{\text {nd }}$ North Carolina model, improved by Căbulea (2004). 


\section{RESULTS AND DISCUSSIONS}

We proceeded to the non-orthogonal decomposition of the variance and using the SS values was determined the contribution of the variances due tested lines, testers, and also due interaction between them. Variance analysis due genotypes and single-cross hybrids indicates statistically significant differences. Analysis of variance due additive action of tester lines indicates distinctly significant differences. Analysis of variance for the percentage of unbroken plants on the harvesting time is presented in Tab.le 3.

From the statistical and mathematical analysis of involved factors in expressing the analyzed character, it can be noticed that the uncontrollable factors had the biggest contribution (40.5\%), followed by genotype (37.8\%) and the genotypeenvironment interaction (16.4\%).

Regarding the single-cross hybrids, the contribution of testers variance was $39.2 \%$ of total variance, the contribution of tested inbred lines was $21.7 \%$ and the interaction of "tested inbred lines x tester" had 39.1\% contribution. Regarding the breeding of stalk lodging resistance, it seems to be important both the accumulation of additive genes and the presence of non-additive effects on inbred lines crossings, so that the fullsib reciprocal recurrent selection scheme is the proper one, because can simultaneously exploit the additive and non-aditive gene effects (the only disadvantage of this method is the 3 years duration of a selection cycle).

Tab. 4 shows the percentage of unbroken plants under the cobs, the average percentage of unbroken plants in testers and tested lines and the additive and non-additive gene effects.

The average of unbroken plants on harvesting time for the single-cross hybrids experimented in 401 compared culture on 2011 and 2012, was $74.92 \%$. An important contribution to achieving this percentage was given by the used testers, namely the TC 385A and TC 399 inbred lines from Turda Comp B and the line TD 268 related to the first two. The highest percentage of unbroken plants was recorded at the tester inbred line TD $268(80.70 \%)$.

Among the tested inbred lines, the TA 452 line with an average of $79.41 \%$ unbroken plants and additive gene effects $\left(\hat{g}_{\mathrm{m}}\right)$ of $4.49 \%$ and the TE 335 line with $77.51 \%$ unbroken plants and $2.59 \%$ additive gene effects $\left(\hat{\mathrm{g}}_{\mathrm{m}}\right)$, were noted for the general ability of transmitting resistance to stalk lodging.

Tab. 3. Analysis of variance for unbroken maize plants in the cyclic cross system

\begin{tabular}{|c|c|c|c|c|c|c|}
\hline \multirow{2}{*}{ Variability cause } & \multirow[t]{2}{*}{ DF } & \multirow[t]{2}{*}{$s^{2}$} & \multicolumn{2}{|c|}{$\begin{array}{l}\text { Sample F } \\
\text { according to: }\end{array}$} & \multirow{2}{*}{ Semnif. } & \multirow{2}{*}{$\begin{array}{c}\text { Factors } \\
\text { contribution } \\
(\%)\end{array}$} \\
\hline & & & error & $\mathrm{s}_{\mathrm{g}}^{2}$ & & \\
\hline Total & 239 & & & & & \\
\hline Repetitions & 4 & & & & & 2.9 \\
\hline Years & 1 & 298.71 & 8.01 & 2.47 & & 1.8 \\
\hline Error $(\mathrm{Y})$ & 4 & 28.83 & & & & 0.7 \\
\hline Genotypes: & 23 & 278.54 & 7.47 & 2.30 & $*$ & 37.8 \\
\hline Single-cross hybrids (SC-H): & $(20)$ & 284.20 & 7.62 & 2.35 & * & 33.5 \\
\hline - additive actions - testers (At) & $((2))$ & 1112.76 & 29.82 & 9.18 & $* *$ & 13.1 \\
\hline - additive actions - tested lines (Am) & $((6))$ & 205.89 & 5.52 & 1.70 & & 7.3 \\
\hline - non-additive interactions (NA) & $((12))$ & 185.25 & 4.97 & 1.53 & & 13.1 \\
\hline Control hybrids $(\mathrm{CH})$ & $(2)$ & 290.42 & 7.78 & 2.40 & & 3.4 \\
\hline Comparisons SC-H - CH & (1) & 141.75 & 3.80 & 1.17 & & 0.8 \\
\hline Years x Genotypes & 23 & 121.18 & 3.25 & & & 16.4 \\
\hline Error* & 184 & 37.31 & & & & 40.5 \\
\hline
\end{tabular}

* uncontrolled experimental factors 
Tab. 4. Unbroken plants percentage, effects of general combining ability $\left(\hat{\mathrm{g}}_{\mathrm{m}, \mathrm{n}}\right)$ and effects of specific combining ability $\left(\hat{\mathrm{s}}_{\mathrm{mxn}}\right)$ to the cyclic cross system on maize inbred lines

\begin{tabular}{|c|c|c|c|c|c|c|c|c|}
\hline \multirow{2}{*}{$\begin{array}{l}\text { Tested } \\
\text { inbred line }\end{array}$} & \multicolumn{2}{|c|}{ TD 268} & \multicolumn{2}{|c|}{ TC 385A } & \multicolumn{2}{|c|}{ TC 399} & \multirow{2}{*}{$\begin{array}{c}\begin{array}{c}\text { Average } \% \\
\text { of unbroken } \\
\text { plants }(\mathrm{m})\end{array} \\
\mathrm{x}^{-} \\
\end{array}$} & \multirow{2}{*}{$\begin{array}{c}\text { Inbred } \\
\text { line G.C.A. } \\
\left(\hat{\mathrm{g}}_{\mathrm{m}}\right) \\
\hat{\mathrm{g}}_{\mathrm{m}} \\
\end{array}$} \\
\hline & $\%$ & $\hat{\mathrm{s}}_{\mathrm{mxn}}$ & $\%$ & $\hat{\mathrm{s}}_{\mathrm{mxn}}$ & $\%$ & $\hat{s}_{\mathrm{mxn}}$ & & \\
\hline TE 229 & 80.78 & 0.30 & 69.83 & -0.78 & 73.50 & 0.48 & 74.71 & -0.22 \\
\hline TE 202B & 82.07 & 5.43 & 55.52 & -11.25 & 75.00 & 5.82 & 70.86 & -4.06 \\
\hline TA 452 & 81.12 & -4.07 & 82.90 & 7.58 & 74.22 & -3.51 & 79.41 & 4.49 \\
\hline TE 330A & 78.37 & -2.56 & 72.53 & 1.48 & 74.53 & 1.07 & 75.14 & 0.22 \\
\hline TD 364 & 77.07 & 1.09 & 70.22 & 4.11 & 63.32 & -5.20 & 70.20 & -4.72 \\
\hline TE 317 & 85.77 & 3.37 & 69.80 & -2.73 & 74.30 & -0.64 & 76.62 & 1.70 \\
\hline TE 335 & 79.73 & -3.56 & 74.98 & 1.57 & 77.82 & 1.99 & 77.51 & 2.59 \\
\hline $\begin{array}{c}\text { Average \% of } \\
\text { unbroken plants (n) }\end{array}$ & 80.70 & & 70.83 & & 73.24 & & 74.92 & \\
\hline Tester G.C.A. $\left(\hat{\mathrm{g}}_{\mathrm{n}}\right)$ & & 5.78 & & -4.10 & & -1.68 & & \\
\hline LD & & P 5\% = & $95 \%$ & & $=9.17 \%$ & & $\mathrm{P} 0.1 \%=11$. & \\
\hline
\end{tabular}

G.C.A. $/ \hat{\mathrm{g}}_{\mathrm{m}}=$ general combining ability / additive genic effects; $\hat{\mathrm{s}}_{\mathrm{mxn}}=$ non-additive genic effects (specific combining ability); LD = limited differences; $\mathrm{p}=$ transgression probability

In the tested compared culture, the percentage of unbroken plants ranged from $55.52 \%\left(\hat{\mathrm{s}}_{\mathrm{mxn}}=\right.$ $-11.25 \%$ ) on TE $202 \mathrm{~B} \times \mathrm{TC} 385 \mathrm{~A}$ hybrid to $85.77 \%$ $\left(\hat{\mathrm{s}}_{\mathrm{mxn}}=+3.37 \%\right)$ on TE $317 \times$ TD 268 hybrid. The highest values for specific combining ability (non-additive gene effects) were recorded at the following hybrids: TA $452 \times \mathrm{TC} 385 \mathrm{~A}\left(\hat{\mathrm{s}}_{\mathrm{mxn}}=\right.$ $+7.58 \%)$, TE 202B x TC $399\left(\hat{\mathrm{s}}_{\mathrm{m \times n}}=+5.82 \%\right)$ and TE 202B x TD $268\left(\hat{\mathrm{s}}_{\mathrm{mxn}}=+5.43 \%\right)$. In some cases, high absolute values, but negative, were recorded at TE 202B x TC 385A $\left(\hat{\mathrm{s}}_{\mathrm{m} \times n}=-11.25 \%\right)$, TD 364 $\mathrm{x}$ TC $399\left(\hat{\mathrm{s}}_{\mathrm{mxn}}=-5.20 \%\right)$ and TA $452 \times$ TD 268 $\left(\hat{\mathrm{s}}_{\mathrm{mxn}}=-4.07 \%\right)$ hybrids. These values denote that non-additive gene effects are also important in transmitting the sensitivity to breakage.

Comparing the values for additive and non-additive gene effects for the percentage of unbroken stalks under the cob on harvesting time, would seem to indicate close absolute values for both positive and negative gene effects. These results confirm similar distribution of percentages for the contribution of gene variances for both, general and specific combining ability.

The study indicates that the best matches between the studied inbred lines are the folllowing: TA 452 x TC 385A, TE 202B x TC 399 and TE 202B x TC 268. These are the combinations that gave the best resistance to stalk lodging (their non-additive genic effects (specific combining ability) had high and positive values). Our results highlight that the non-additive genic effects are also responsible for transmition of sensitivity to stalk lodging (TE 202B x TC 385A hybrid). So, we can conclude that in the process of inbred lines creation for resistant commercial hybrids to stalk lodging, it is necessary during the inbreeding generations to exert selection pressure in order to obtain the most resistant genotypes, including by testing at high volumes and by infesting the base of stalks with Fusarium spp. suspensions. It is also necessary in the selection process of hybrids to retain only hybrid combinations with resistance, since the additive and non-additive gene effects appear to have similar contributions in the development of resistant genotypes to stalk lodging.

\section{CONCLUSIONS}

The highest percentage of unbroken plants was recorded for hybrids made with the TD 268 tester line. Regardind the tested lines, the TA 452 line was noted. 
The results show the importance of genes with additive effects in transmission of stalk lodging resistance; non-additive effects are also important due to the correlation between them and the percentage of unbroken plants at harvest.

In the hybrid selection process only those hybrid combinations resistant to stalk lodging need to be retained due to similar contributions of additive and non-additive genes effects in the development of resistant genotypes to stalk breakage.

\section{REFERENCES}

1. Căbulea I, Ocheșanu C, Nagy E, Haș V, Maroșan V (1981). Cercetări privind posibilitățile genetice de creare a hibrizilor de porumb productivi, timpurii și rezistenți la cădere. Analele I.C.C.P.T. Fundulea, XLVI:15-24

2. Căbulea I (2004). Genetica porumbului, În: Butnaru G, Căbulea I, Cristea M, Haș, I Haş V, Malschi D, Mureşan F, Nagy E, Perju T, Sarca T, Sarca V, Scurtu D, Porumbul studiu monografic. Ed. Academiei Române, Bucureşti.

3. Flint-Garcia, S.A., C. Jampatong C, L.L. Darrah LL, M.D. McMullen MD, (2003)., Quantitative trait locus analysis of stalk strength in four maize populations,. Crop Science, 43:13-22.

4. Hallauer AR, Carena MJ, Miranda Filho JB (2010) Quantitative genetics in maize breeding. $3^{\text {rd }}$ ed., Springer, New York, NY.

5. Haș I (2004). Heterozisul la porumb, În: Butnaru G, Căbulea I, Cristea M, Haş, I Haş V, Malschi D, Mureşan F, Nagy E, Perju T, Sarca T, Sarca V, Scurtu D, Porumbul studiu monografic. Ed. Academiei Române, București.

6. Haș I, Haș V, Mureșan E, Ifrim S (2010). Folosirea descompunerilor ortogonale și neortogonale în compararea unor grupe de genotipuri. Analele INCDA Fundulea, 78(2):5-16.

7. Haș V, Haș I, Chicinaș C, Șchiop T, Coste ID, Tritean N (2011). Valoarea fenotipică și genetică a unor linii consangvinizate isonucleare de porumb. Analele INCDA Fundulea LXXIX:49-66.

8. Huang, H., D. Chen D, Y. Chang Y, W. Hu W, C. Wu C, Y. Gu Y, (2014)., Studies on variances of the lodging-resistant ability and the mechanism in different maize varieties,. Journal of Nanjing Agricultural University, vol.37(4): 2230.
9. Larsson, Sara J., J.A. Peiffer JA, J.W. Edwards JW, E.H. Ersoz EH, S.A. Flint-Garcia SA, J.B. Holland JB, M.D. McMullen MD, M.R. Tuinstra MR, Cinta Romay C, E.S. Buckler ES, (2017)., Genetic analysis of lodging in diverse maize hybrids, preprint bioRxiv: 185769; doi: https://doi. org/10.1101/185769.

10. Liu, Z., S. Li S, J. Yang J, Y. Yang Y, C. Mi C, H. Wamg H, W. Hu W, X. Zhang X, D. Zhu D, (2010)., Method of test environments selection for corn lodging resistance,. Transactions of the Chinese Society of Agricultural Engineering, vol.26(10): 167-171.

11. Lu, H., J. Qiao J, J. Liu J, L. Xia L, W. Zhu W, C. LIi C, Q. Zhou $Q$ (2015)., Research on the relationship between maize lodging resistance and grain mechanically harvesting qualities in different planting density,. Acta Agriculturae Boreali-Sinica, vol. 30(2): 198-201.

12. Ona, Andreea-Daniela, (2014)., Studiul fenotipic și genotipic al unor linii consangvinizate obținute din două composite heterotice de porumb,. Teză de doctorat, ClujNapoca.

13. Ona A, Haș I, Haș V, Pop R (2013). Study of yield potential of maize single-cross hybrids in cyclic cross system. Research Journal of Agricultural Science, 45(4):145-150.

14. Peiffer, J., S. Flint-Garcia S, Natalia de Leon N, M.D. McMullen MD, S.M. Kaeppler SM, E.S. Buckler, ES, (2013)., The genetic architecture of maize stalk strength,. PLoS ONE, 8(6):e67066.doi:10.1371/journal.pone .0067066.

15. Robertson, D., S.Y. Lee, SY, Margaret Julias M, D.D. Cook DD, (2016)., Maize stalk lodging: Flexural stiffness predicts strength,. Crop Science, 56:1711-1718.

16. Robertson, D., Margaret Julias M, S.Y. Lee SY, D.D. Cook DD, (2017)., Maize stalk lodging: Morphological determinants of stalk strength,. Crop Science, 57:926-934.

17. Suciu, Alexandra Loredana, (2009)., Cercetări privind biologia și ecologia speciilor de Fusarium și controlul integrat al fuzariozelor porumbului,. Teză de doctorat, Cluj-Napoca.

18. Troyer AF (1999). Background of U.S. hybrid corn, Crop Science, 39:601-626.

19. Xue, J., L. Gou L, Y. Zhao Y, Minna Yao M, H. Yao H, J. Tian J, W. Zhang, W (2016)., Effects of light intensity within the canopy on maize lodging,. Field Crops Research, 188:133141.

20. Yang, S., Y. Liu Y, D. Zhang D, Z. Zhang Z, J. Zhang J, L. Zhu L, Y. Huang Y, Y. Zhao Y, J. Guo J, J. Chen J, (2016)., Maydica, 61(4). 